\title{
IMPROVING THE PERFORMANCE AND EMISSIONS OF A FOUR-STROKE, WATER-COOLED, DI DIESEL ENGINE BY INCREASING INLET AIR TEMPERATURE
}

\author{
Mohsen M. Abdelaal, Basem A. Rabee, Mohammad A. Kamel* \\ Department of Mechanical Engineering, Al-Azhar University, Cairo 11371, Egypt \\ *Corresponding Author: Mohammad A. Kamel; kamel_822001@yahoo.com \\ Received :19 Augst. $2021 \quad$ Accepted:6 Oct. 2021
}

\begin{abstract}
The inlet air temperature of a diesel engine plays a dominant role in its efficiency as it affects the combustion parameters, provided the engine characteristics are suitably adjusted. This study investigates the effect of inlet air temperature on the performance and emissions of a singlecylinder, four-stroke, water-cooled, direct-injection diesel engine. Inlet air was preheated up to 90 ${ }^{\circ} \mathrm{C}$ and its impact was observed using the Diesel-RK software simulator under constant engine speed and variable load conditions. Air-preheating increases the physical and chemical delay rates - i.e., it accelerates the droplet vaporization and combustion rates. However, this also reduces its density, thereby lowering its mass flow rate and cycle efficiency, which is counterproductive. Therefore, the inlet air density must be increased to its original value beforehand to yield the full benefits of air-preheating. Furthermore, the effect of increased fuel flow rate at $30 \%$ of its rated value was also investigated; combined with increased air density, this caused a spike in the rated power, leading to improvements in the engine performance and combustion efficiency. These results show that preheating the intake air by increasing the fuel and intake air mass could improve the power-to-mass ratio of existing engines and reduce its pollutant emissions.
\end{abstract}

Keywords: Diesel engine, inlet air temperature, inlet air preheating, air-fuel ratio, physical and chemical delay, ignition delay, exhaust emissions. 


\title{
تحسين أداء وتقليل الإبعاثات لمحرك ليزل رباعي الأشواطتبريد مياه احادي الأسطوانة وذنك عن طريق زيادة درجة

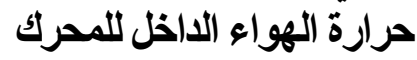

\author{
محمد أحمد كامل*، باسم عبدالله ربيع ، محسن محمد عبدالعال \\ قسم الهندسة الميكانيكيه , كلية الهندسة , جامعة الازهر , القاهرة , مصر
}

kamel_822001@yahoo.com البريد الاليكتروني للباحث الرئيسى:

\begin{abstract}
الملخص
أداء محركات الديزل تتأثر بتغيير درجة حر ارة الهو اء الداخل الي الدحرك لأنها تؤثر علي خصائص تفاعلات الحريق وبالتالي يمكن توظيف

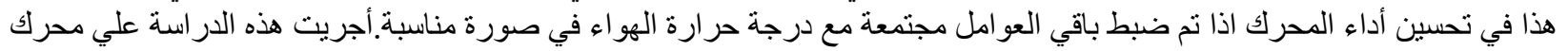

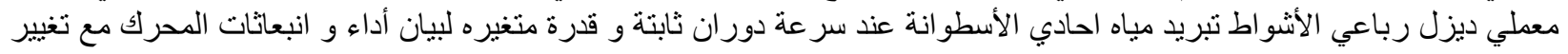

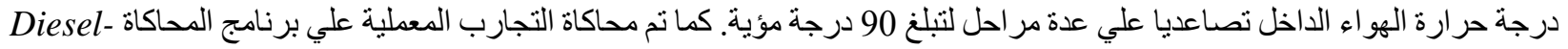

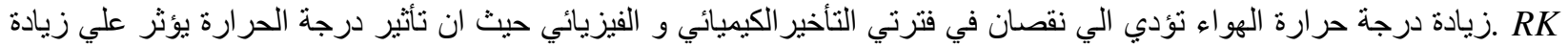

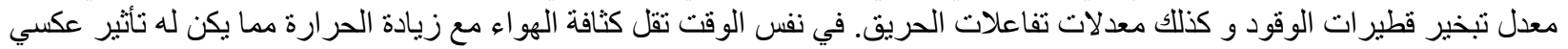

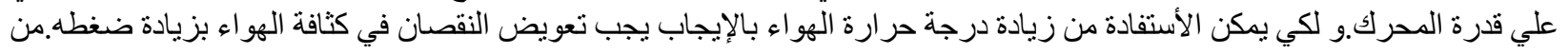

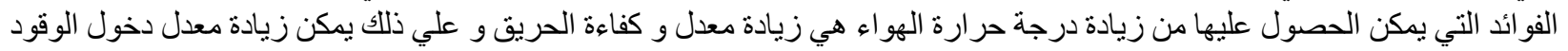

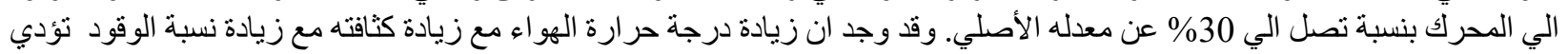
الي تحسن في أداء المحرك و كفاءة الحريق و زيادة قدرة المحرك وبالتالي زيادة لئل نسبة "القدرة الي الكتلة" للمحرك.
\end{abstract}

الكلمات المفتاحية : محركات الديزل, درجة حرارة الهواء الداخل الي المحرك, تسخين الهواء الداخل للمحرك ,التأخيرالكيميائي و القيزيائي, الإنبعاثات الفئات

\section{Introduction}

The inlet air temperature of a diesel engine has a dominating effect on its performance and emissions. This may be attributed to its direct impact on fuel spray characteristics. The temperature of the inlet air affects that of the injected diesel-spray droplet; higher temperatures lead to easier droplet evaporation and facilitate its subsequent mixing with the inlet air, thereby reducing the delay in physical ignition. Any variation in the temperature of inlet air also changes its density, which in turn affects the spray-tip penetration and the spray cone angle [1-3]; this influence on the overall spray characteristics has been experimentally and numerically quantified in several studies. Park et al. [1] found that a rise in air temperature boosts spray-tip penetration and reduces the spray cone angle while Jaat et al. [3] found that the spray area and angle increase with temperature.

Several researchers have studied the effects of preheated air on engine performance and emissions. Inlet air temperature affects parameters, such as the air-fuel ratio, fuel vaporization rate, and mixing efficiency of air and fuel, which in turn influences aspects, such as fuel consumption, brake thermal efficiency (BTE), and exhaust emission. Owing to advances in spray evaporation and airfuel mixing, an increase in the inlet air temperature is correlated with several benefits, such as improvements in fuel consumption and BTE, along with a modest decline in the levels of carbon monoxide $(\mathrm{CO})$ in the exhaust gas. However, it also leads to increased emissions of nitrogen oxide (NOx) gases $[1,2,5,6,8,10,11,13-15]$. 
Shahadat et al. [4] studied the effects of preheated inlet air and the exhaust gas recirculation (EGR) technique on engine performance. The hot exhaust gas was used to warm up the inlet air passing through a novel air-preheating system. Combining the dual aspects of air-preheating and the EGR system resulted in better engine performance than implementing the individual aspects. This simultaneous implementation also led to reduced levels of CO and NOx, engine noise, and brakespecific fuel consumption at medium loads, when compared to those during normal operations of the engine.

Raghuwanshi et al. [6] demonstrated the effects of preheating both diesel and inlet air on engine performance. Preheating, conducted by the recovery and utilization of waste heat that would otherwise be expelled to the environment via exhaust gases, subsequently reduces the levels of CO and hydrocarbon (HC) emissions, although it does have the undesirable effect of increasing NOx emissions. Further effects include a decrease in BTE and an increase in overall emission levels due to a reduced air-fuel ratio [7,9].

Mhia et al. [12] studied the effect of inlet air preheating via exhaust gases on the combustion and exhaust emissions using a neat diesel fuel and diesel kerosene blend in a diesel engine. Their experimental results showed that at elevated inlet air temperatures after warming up the engine, the NOx and $\mathrm{CO}$ emissions, as well as engine noise, decrease for medium load conditions using the newly designed system. Comparatively better overall engine performance is found for high load conditions using the same system. The reduction in emissions may be attributed to a significant reduction in ignition delay and better combustion due to higher inlet air temperatures. The internal combustion engine is indispensable to modern life. Researchers and manufacturers of these engines face critical problems, the most important of which are high fuel prices and air pollution. To overcome these limitations, research is being conducted to reduce emissions and improve fuel consumption and engine performance. This requires a deep understanding of the nature of fluid flow and the combustion phenomena in these engines. Simulation of diesel engines is one of the most important means to help achieve these targets. Several studies have used the Diesel-RK software to simulate internal combustion engines. Effects of different parameters and combustion chamber geometry on the combustion phenomenon, spray characteristics, engine performance, and emissions were modelled in Diesel-RK and compared with experimental observations. Additionally, different fuels such as diesel and biodiesel were used in these investigations. A good agreement was observed between the model and experimental data, thereby validating the model [16-25].

This study experimentally investigates the effect of inlet air temperature on diesel engine performance and exhaust emissions. Based on experimental results, a computational analysis was conducted for the same experimental conditions.

Existing research utilize two different increased intake air temperature approaches. The first approach showed increased BTE and decreased emissions, whereas the second approach showed decreased BTE and increased emissions to some extent. The present study, after employing an intensive experimental program, showed that the BTE increase, emissions decrease, and engine power-to-mass ratio increase by preheating the intake air is achieved in the case of increasing the intake air and fuel mass simultaneously; otherwise, the improvement is limited to a low engine power range (up to $20 \%$ load).

\section{Experimental apparatus and procedure}


This study was conducted on a Petter PH1W single-cylinder, naturally aspirated, four-stroke, water-cooled, high-speed, direct-injection (DI) diesel engine, complete with a heavy flywheel. Engine specifications are given in Table 1 .

\begin{tabular}{lc}
\hline Model & Petter PH1W diesel engine \\
\hline Engine configuration & Single-cylinder, four-stroke, water-cooled \\
Bore & $87.3 \mathrm{~mm}$ \\
\hline Stroke & $110 \mathrm{~mm}$ \\
Compression ratio & $16.5: 1$ \\
\hline Rated power and speed & $6.3 \mathrm{bhp} @ 1500 \mathrm{rpm}$ \\
Fuel Injection system & Direct injection (DI) \\
Injection pressure & $200 \mathrm{bar}$ \\
Number of nozzles per injector & 3 \\
Nozzle diameter & $0.25 \mathrm{~mm}$ \\
Spray angle & $120^{\circ}$ \\
Injection timing & $24^{\circ} \mathrm{BTDC}$ \\
Valve timing & Opening Closing \\
Intake & $4.5^{\circ} \mathrm{BTDC} 35.5^{\circ} \mathrm{ABDC}$ \\
Exhaust & $35.5^{\circ} \mathrm{BBDC} 4.5^{\circ} \mathrm{ATDC}$ \\
\hline
\end{tabular}

Table 1: Engine specifications

The engine is modified to meet the requirements of preheating the inlet air. A schematic of the testbed is shown in Fig. 1.

The air intake system regulated the amount of air introduced into the cylinder. A damping reservoir and an orifice system were used to measure the mass flow rate of air supplied to the engine, while accounting for the pulsation effect of the engine suction. An electrical air pre-heater was used for preheating, while a burette and a stopwatch were used to measure the volumetric flow rate of diesel. A combustion pressure sensor (PCB Piezotronics) was used to measure the pressure inside the engine cylinder, while a magnetic pickup sensor with a resolution of one degree was used to indicate the top dead centre and regular intervals of the crank angle position as well. A dualchannel, high-speed (400 MHz), digitizing, real-time oscilloscope (Tektronix) was used to present and record the output pressure-crank-angle signals. A multi-gas analyser (ADC Gas Analysis Company) was used to measure the concentrations of exhaust gas components, such as $\mathrm{NO}, \mathrm{CO}$, carbon dioxide, and oxygen (O2). The first three gases were measured based on the infrared absorptivity principle using the infrared gas analyser, whereas the latter was measured based on the paramagnetic characteristics of $\mathrm{O} 2$, using a paramagnetic oxygen analyser. A flame-ionization detector (CAI) was used to measure $\mathrm{HC}$ emissions. 


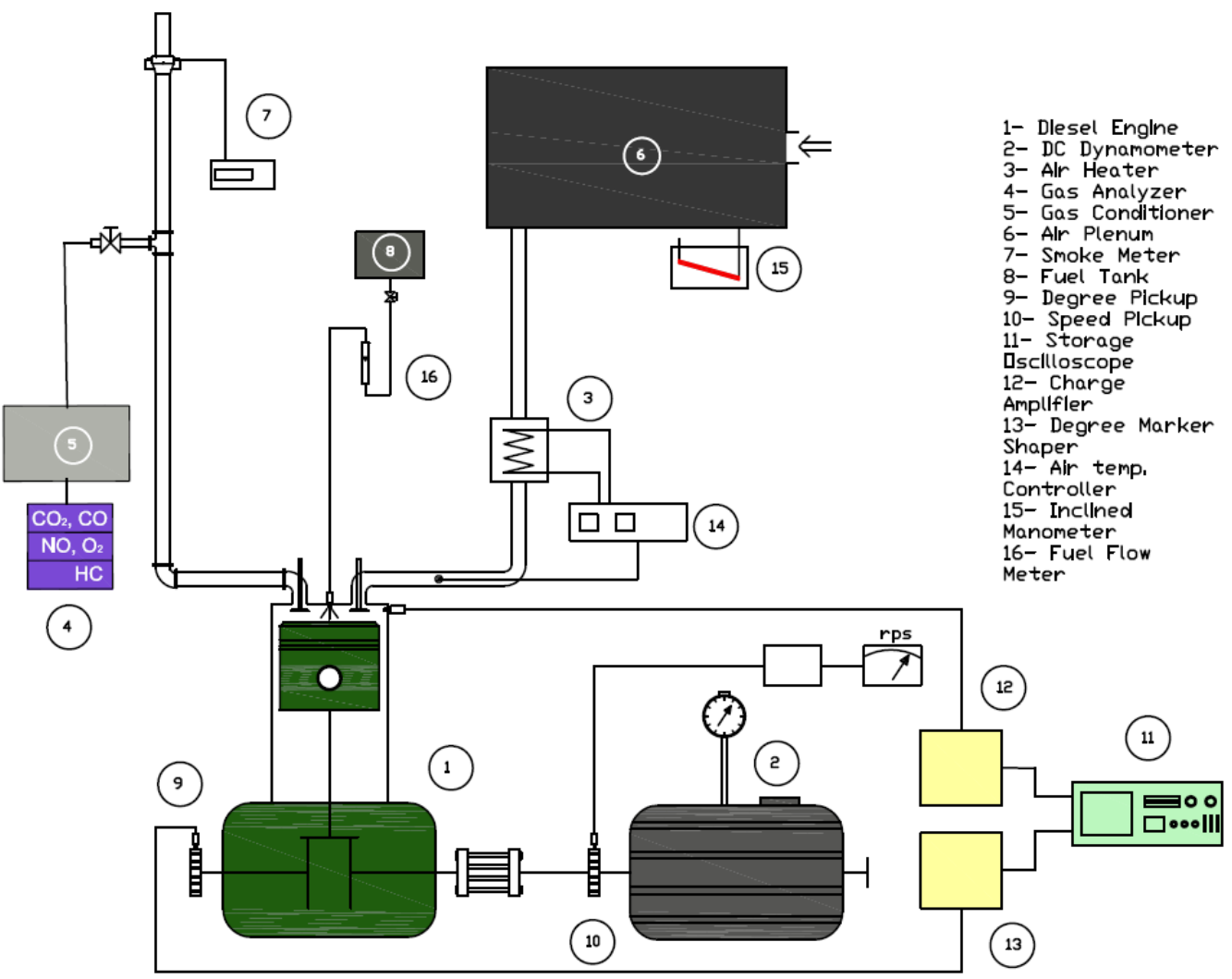

Figure 1: Test bed schematic.

\section{1 . Experimental methodology}

\subsubsection{Experimental set-up and test conditions}

This work investigated a diesel engine to determine the effect of inlet air preheating on performance and emissions, for which a comprehensive experiment was carefully designed. In this study, the experiments were conducted in two phases:

I. In the first phase, the engine was operated without any preheating of the inlet air.

II. In the second phase, the engine was suitably modified to preheat the inlet air to temperatures of 50,70 , and $90{ }^{\circ} \mathrm{C}$.

For both phases, experiments were conducted at a constant engine speed of $1500 \mathrm{rpm}$ over a wide range of loads that lay between 16-85\% of the engine's rated load at that speed. A complete set of measurements were taken for engine performance, exhaust gas emissions and concentrations, and cylinder pressure data. 


\subsubsection{Computational analysis model}

This study uses Diesel-RK to model the performance of the diesel engine and analyse its emissions and cylinder pressure data.

Diesel-RK is a full-cycle modelling and simulation software specifically developed for thermodynamic engine simulation. Developed in 1981-82 in the department of Internal Combustion Engines (Piston Engines) of the Bauman Moscow State Technical University in Russia, it models and optimizes the working processes of internal combustion engines at all levels of boosting. This software is used in the prediction of torque curves, engine performance, and fuel consumption, in the analysis of emissions, and in the optimization of fuel injection profiles that include multiple injections, sprayer design and location, and the shape of the piston bowl in models of DI diesel engines [16].

Our simulation was conducted in two phases:

1. Conventional mode of operation without the preheating of intake air, to set baseline levels for validating the simulation results with the experimental results.

2. Experimental mode of operation involving the preheating of intake air to $90{ }^{\circ} \mathrm{C}$. The volumetric flow rate of air was increased to compensate for the drop in density attributed to heating, thereby retaining its original mass flow rate corresponding to the non-preheating condition. This also involved increasing the mass flow rate of the fuel by up to $30 \%$ more than its mass in the preheating case.

For both phases, the simulation was performed at a constant engine speed of $1500 \mathrm{rpm}$ over a wide range of loads that lay between $16 \%-85 \%$ of the rated load at that speed.

\section{Results and discussion}

In summary, this study investigated the effect of preheating the inlet air in a diesel engine on its emissions and performance. A simulation was performed with the Diesel-RK software and validated with experimental results from operations conducted without preheating. Fig. 2-6 compare the theoretical and experimental results for in-cylinder pressure, BTE, volumetric efficiency, nitric oxides, and smoke emission levels, respectively. These results show a good agreement between the experimental data and the theoretical model. As any errors in the input data could lead to deviations of the simulation results from the experimental results, the Diesel-RK software precisely matches the input parameters with the experimental results. An additional possible use of this software lies in the simulation and investigation of the functioning of the engine at operating conditions that may be difficult to mimic in an experimental set-up. Table 2 indicates the error between the theoretical and experimental results.

Table 2: Error between the theoretical and experimental results

\begin{tabular}{|c|c|}
\hline & Average error (\%) \\
\hline BTE & 3.15 \\
\hline Volumetric efficiency & 0.03 \\
\hline $\begin{array}{c}\text { Nitric oxides emission } \\
\text { index }\left(\mathrm{EI}_{\mathrm{NO}_{\mathrm{x}}}\right)\end{array}$ & 26.63 \\
\hline Smoke emission \% & 3 \\
\hline
\end{tabular}


Figs. 7-11 display the effect of preheating on engine performance and on its NOx and smoke emissions; air is preheated to temperatures of $50{ }^{\circ} \mathrm{C}, 70^{\circ} \mathrm{C}$ and $90{ }^{\circ} \mathrm{C}$.

Fig. 7 compares the experimental in-cylinder pressures corresponding to the cases of nonpreheated and preheated air - with the engine operating at $85 \%$ of its rated load and a speed of $1500 \mathrm{rpm}$ - and shows that preheating leads to a reduction in ignition delay and peak pressure. This can be explained as follows: ignition delay consists of two parts - physical ignition delay involving the vaporization of the atomized fuel and chemical ignition delay involving the rate of combustion. Consequently, preheating, by providing more thermal energy to the mixture, increases not only the rate of vaporization of the atomized fuel, but also the chemical reaction rate. The amount of premixed fuel in the rapid, uncontrolled combustion stage is also reduced, which in turn leads to a decline in peak pressure.

Fig. 8 shows experimental results for the BTE values in both modes of operation - non-preheating and preheating. At less than 50\% of the rated load, BTE did not vary appreciably with air temperature. At loads over $50 \%$ of the rated value, however, the engine suffers marginally lower efficiencies at higher air temperatures. This can be attributed to a reduction in the density of inlet air at higher temperatures, which in turn lowers the mass of a given volume of air. Additionally, the normalized mass of air (ratio of the masses of non-preheated and preheated air) is reduced at elevated inlet air temperatures, as shown in Fig. 9.

Fig. 10 shows experimental results regarding the emission of nitric oxides (NOx), in terms of an emission index, for both non-preheated and preheated modes of operation. It is evident that an increase in inlet air temperature leads to a corresponding increase in the overall temperature inside the cylinder and, consequently, the rate of formation of nitric oxides.

As illustrated above, increasing the inlet air temperature within the normal operating range of the engine while maintaining the other operating parameters constant (injection timing, injection pressure, injection nozzle geometry, etc.) does not yield the required improvement. This can be explained by the following reasons:

1- Reduced density of inlet air, resulting in a consequent drop in its mass flow rate

2- Improved vaporization of fuel, resulting in a reduction of the air-fuel ratio

3- Shortened ignition-delay period, which changes the duration of combustion

Supercharging was expected to improve BTE values in the face of air-preheating by increasing its density. Additionally, increasing the amount of fuel injected can increase the operating range outside the smoke region. These aspects were theoretically modelled in Diesel-RK because modifying the engine would be laborious and expensive. The intake air pressure (and thereby its density) was increased to retain the mass flow rate used in the non-preheating condition and the fuel input was increased by $30 \%$ of the rated amount. Results quantifying the impact of these aspects were presented and compared with those from the non-preheating scenario.

Because smoke levels reflect the amount of soot emitted, combustion efficiency is inversely related to soot emissions and smoke levels. Air temperature, because of preheating in the diesel engine, has direct and inverse correlations to combustion efficiency depending on the percentage of the rated load at which the engine is operating. This can be explained as follows: when air is preheated, its density decreases, leading to reduced mass flow rates of it into the engine. This, in turn, lowers the air-fuel ratio for a given mass of fuel. At low loads, the ratio is high (about $45 \%$ in this study); a reduction from such large levels does not limit the amount of air available for combustion. 
Additionally, preheating improves reaction rates and hence increases combustion efficiency, resulting in low levels of soot and smoke. On the other hand, the air-fuel ratio at higher loads is already limited; reduced mass flow rates of air arising from preheating further decreases it, thereby restraining the amount of $\mathrm{O} 2$ available for combustion. This, in turn, lowers the combustion efficiency, resulting in higher levels of soot and smoke. Therefore, the variation of the smoke levels of non-preheated and preheated air with engine load shows a reverse trend, as shown in Fig. 11 .

To neutralize the effect of preheating on air density (and thereby on smoke levels), a smoke level correction factor was introduced as follows:

Corrected smoke level $=$ smoke level number $\mathrm{x}$ (preheated air density / non-preheating air density)

The corrected smoke level results, as presented in Fig. 11, indicate that the amount of air available for combustion has a major impact on its efficiency, particularly at higher loads. Therefore, to harvest all the benefits of preheating, a supercharger should be used to increase the intake of preheated air to the same level as that of non-preheated air.

Fig. 12 compares the simulated values of BTE for non-preheated air, air preheated to $90{ }^{\circ} \mathrm{C}$, and excess air (along with $30 \%$ excess fuel) preheated to $90{ }^{\circ} \mathrm{C}$. Results showed an improvement of about $2 \%$ in the values of BTE and an increase of $20 \%$ in the engine operating range - i.e., the engine-power-to-mass ratio was found to have increased.

Fig. 13 shows the variation in NOx emission index with engine load for the aforementioned operating conditions. Increased NOx levels were observed with air-preheating and excess fuel. The formed NOx is the thermal NOx; therefore, its formation is direct proportional to the combustion temperature. In the present case, the combustion temperature increased due to airpreheating, supercharging, and combustion energy increase by increasing the fuel amount. Consequently, the thermal NOx was increased, as shown in Fig. 13.

Fig. 14 shows the variation in emitted smoke percentage levels with engine load for the aforementioned operating conditions. Decreased smoke levels were observed with air-preheating and excess fuel, which is due to the air temperature increase. The delay period decreased, so the uncontrolled combustion stage decreased, which resulted in less soot formation. Furthermore, the increase in combustion temperature, as indicated in Fig. 13, enhanced the carbon oxidation process, resulting in less soot formation.

Fig. 15 shows the variation in cylinder pressure for the aforementioned operating conditions. The peak pressure increased with air-preheating, supercharging, and excess fuel, which in turn increased the air pressure and cylinder energy heat release rate, resulting in less delay period and the occurrence of peak pressure in a smaller cylinder volume, i.e., in earlier crank angle degrees.

We compared our results with those of previous studies. Previously, a decrease in BTE and an increase in overall emission levels with preheated intake air due to a reduced air-fuel ratio was reported [7, 9], which matches our experimental results. However, we obtained improved BTE values by preheating the intake air and reduced smoke levels by supercharging. These aspects were theoretically modelled in Diesel-RK because modifying the engine would be laborious and expensive. 


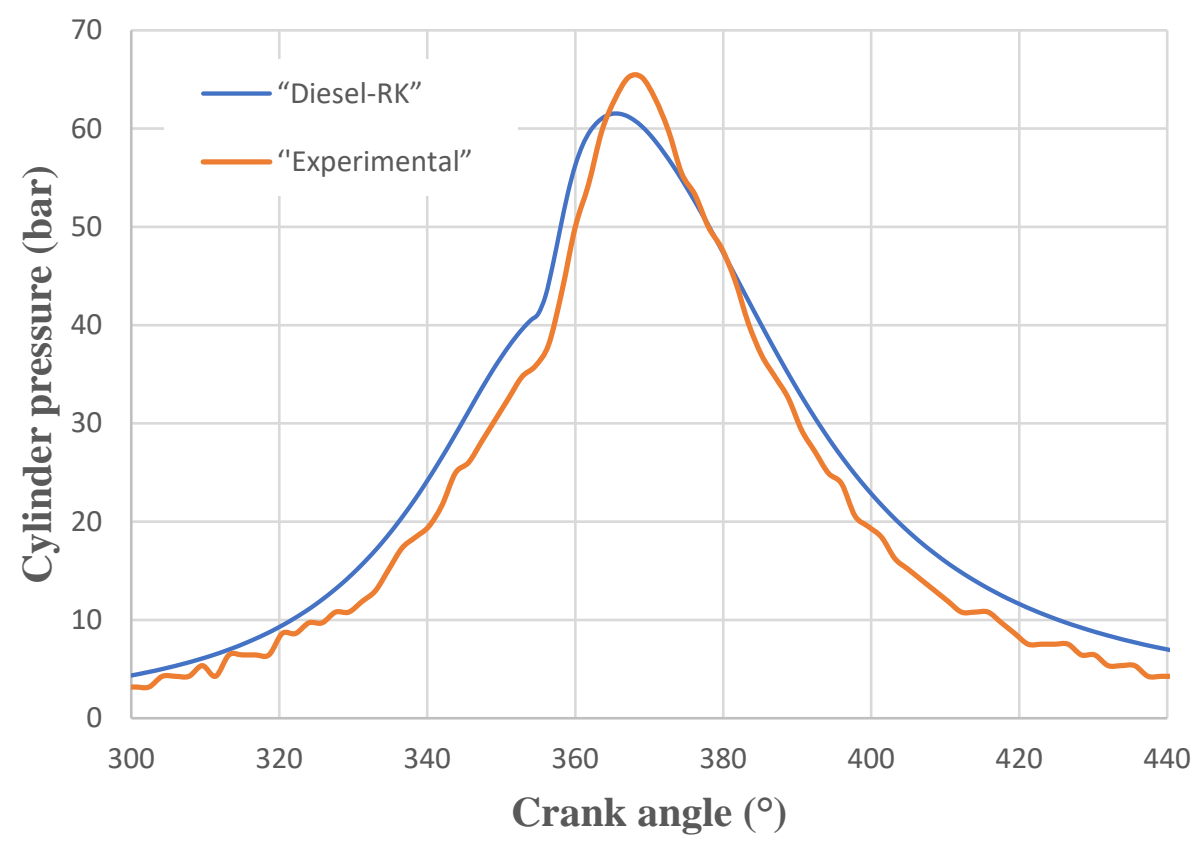

Figure 2: Variation of experimental \& simulated cylinder pressure.

This CAD diagram plots the change in cylinder pressure with crank angle for an engine operating with non-preheated air, at $85 \%$ of the rated load.

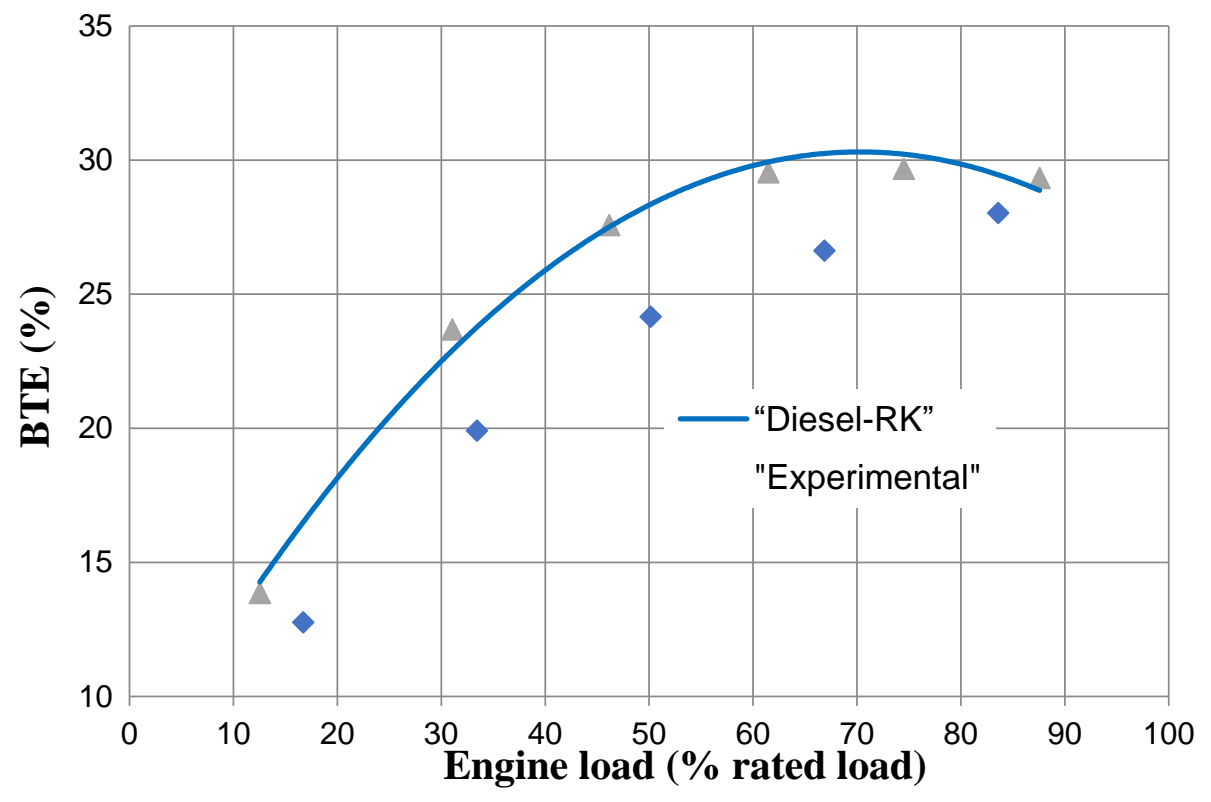

Figure 3: Variation of experimental \& simulated brake thermal efficiency. This CAD diagram plots the change in BTE for non-preheated air. 


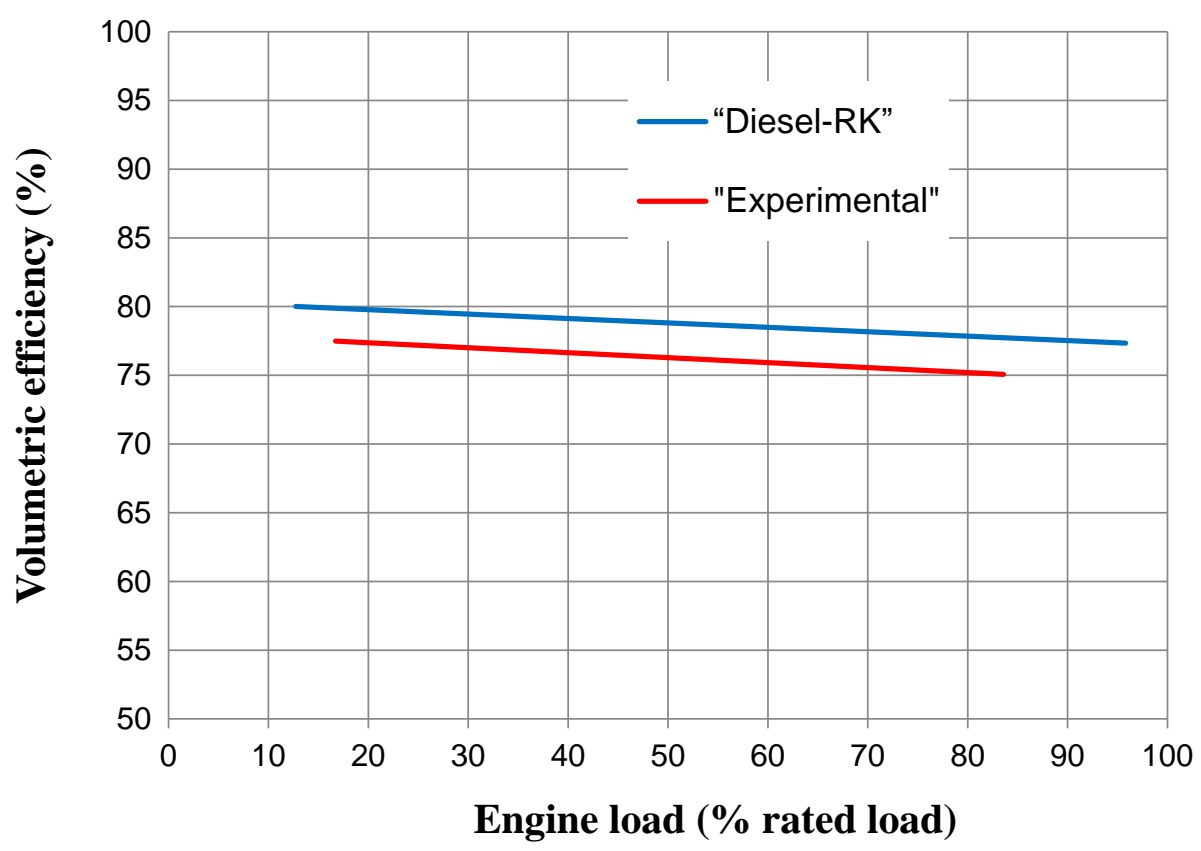

Figure 4: Variation of experimental \& simulated volumetric efficiencies.

This CAD diagram plots the change in efficiency with engine load for non-preheated air.

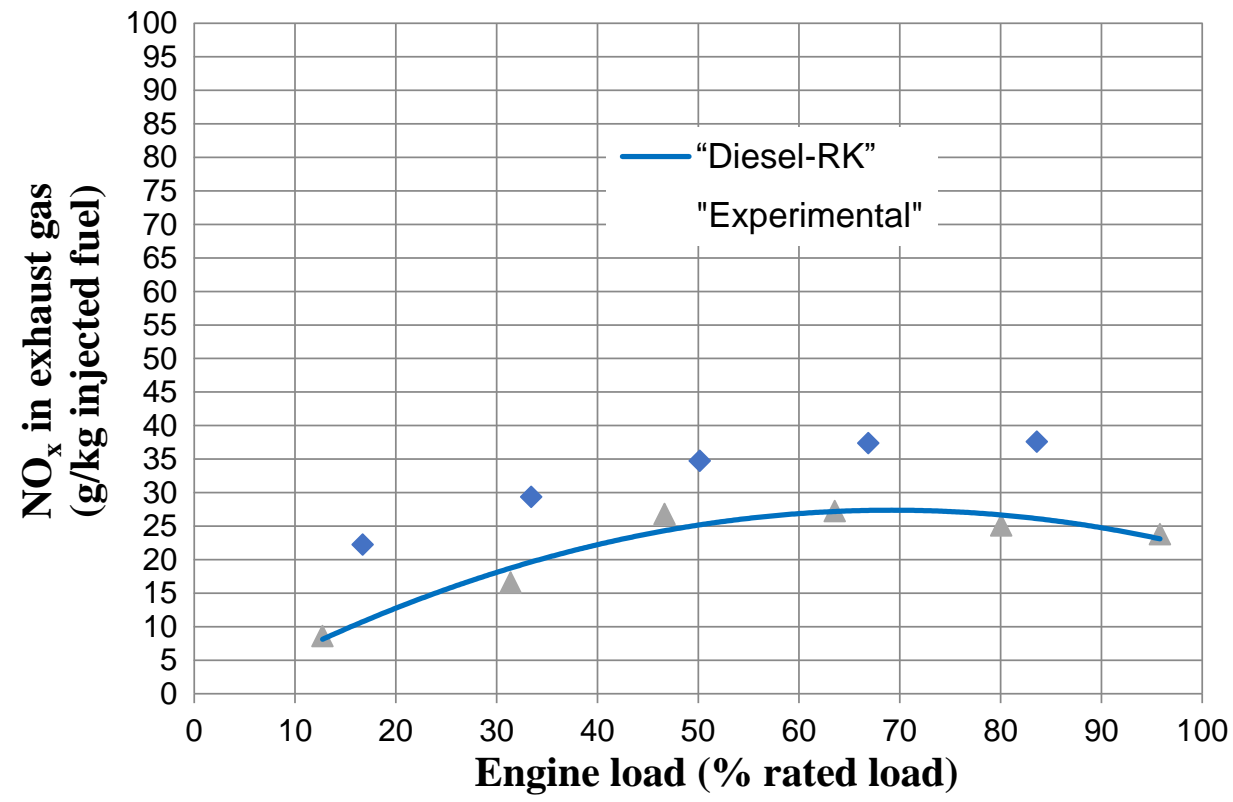

Figure 5: Variation of experimental \& simulated emission index $\left(\mathrm{EINO}_{\mathrm{x}}\right)$.

This CAD diagram plots the change in $\mathrm{EINO}_{\mathrm{x}}$ with engine load for non-preheated air. 


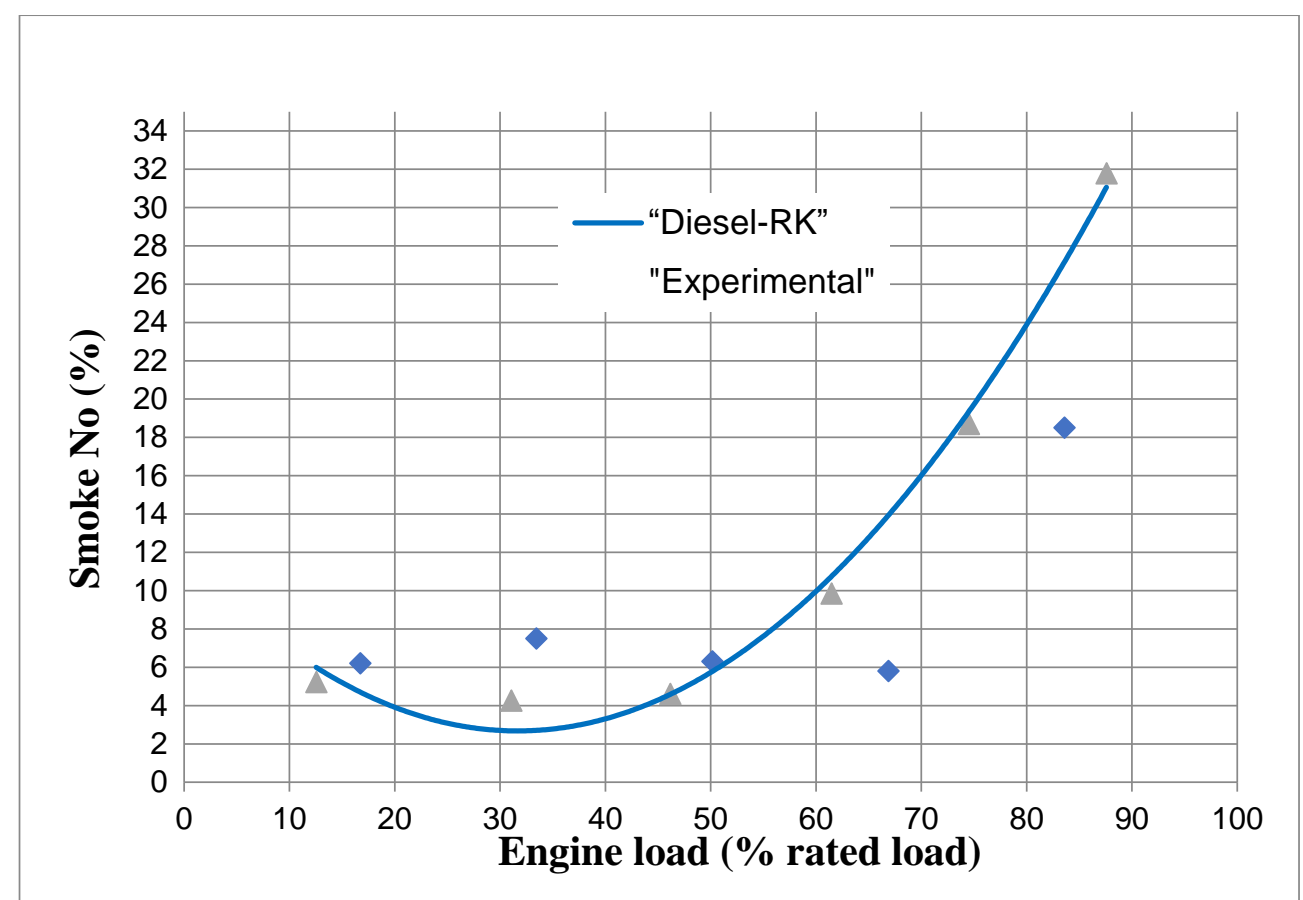

Figure 6: Variation of experimental \& simulated smoke emission levels. This CAD diagram plots the change in smoke levels with engine load for non-preheated air.

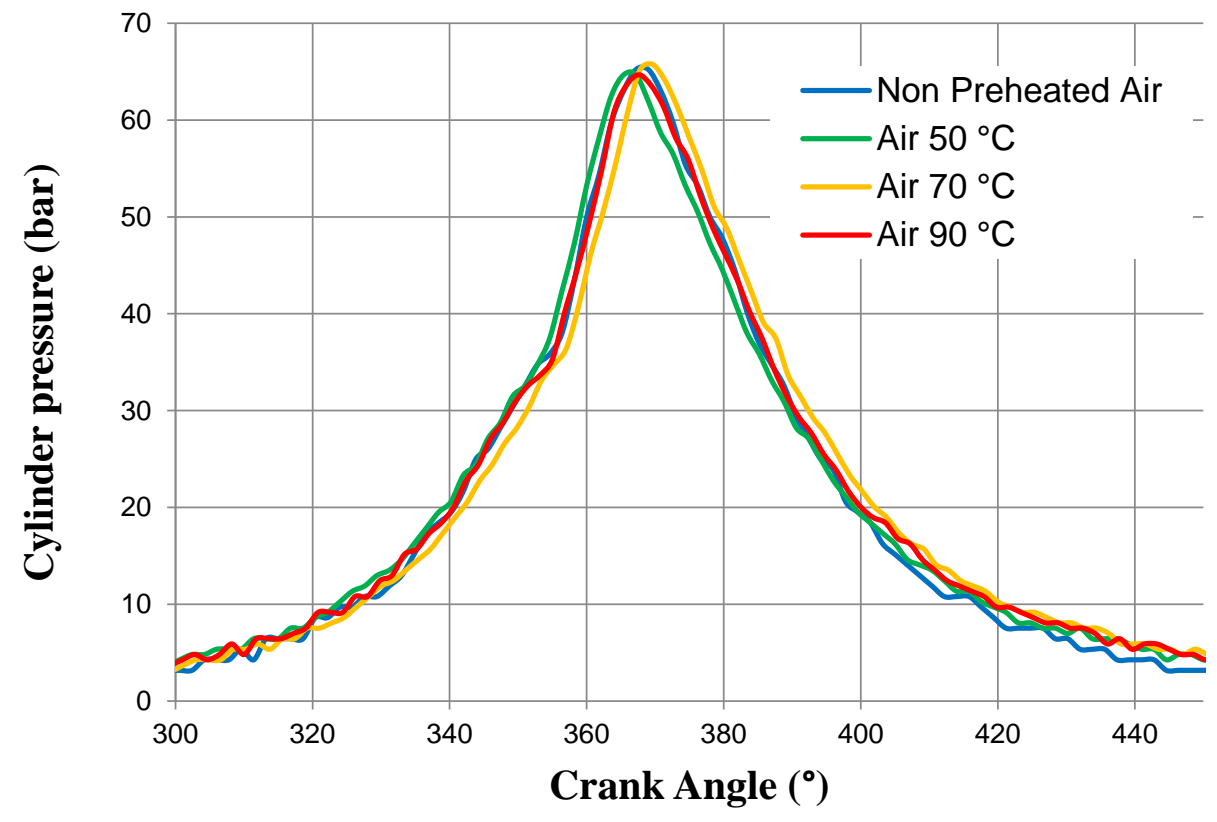

Figure 7: Variation of experimental cylinder pressure.

This CAD diagram plots the change in pressure with crank angle while operating at $85 \%$ of the rated load. 


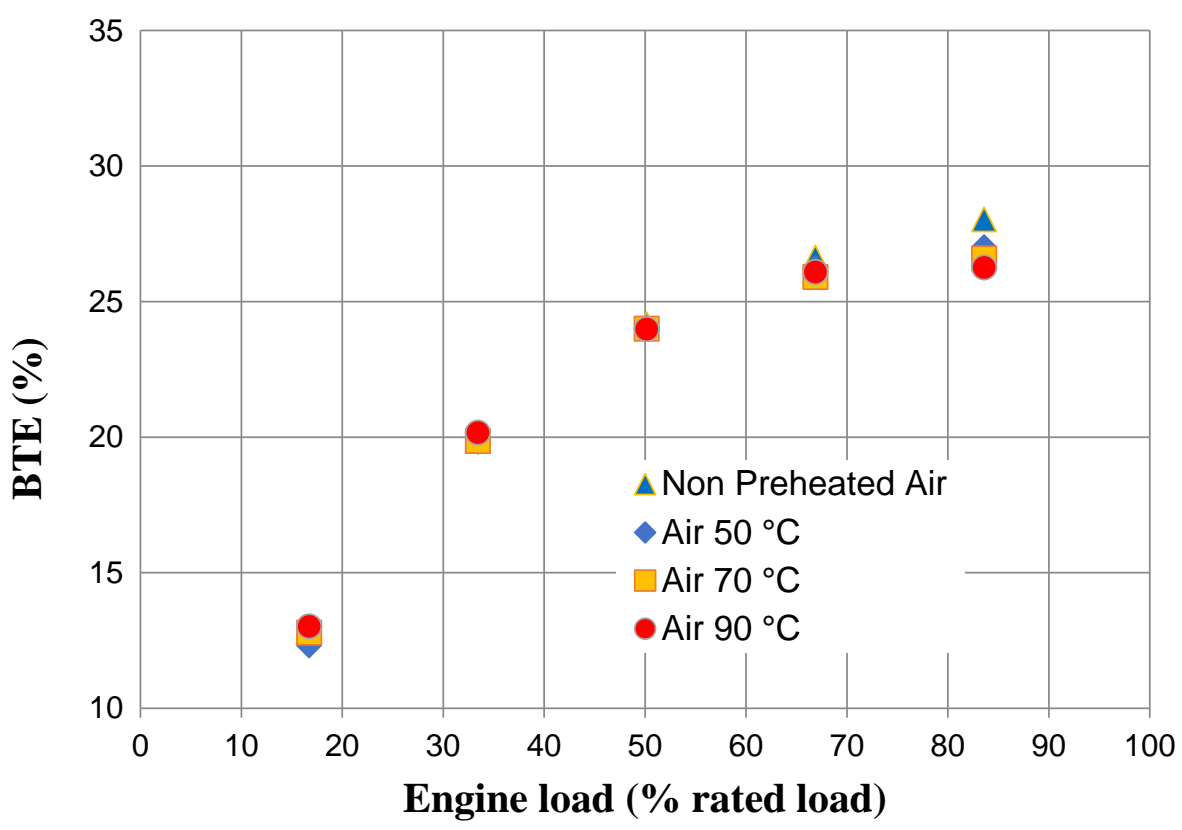

Figure 8: Experimental variations of brake thermal efficiency.

This CAD diagram plots the change in BTE with engine load for various inlet air conditions.

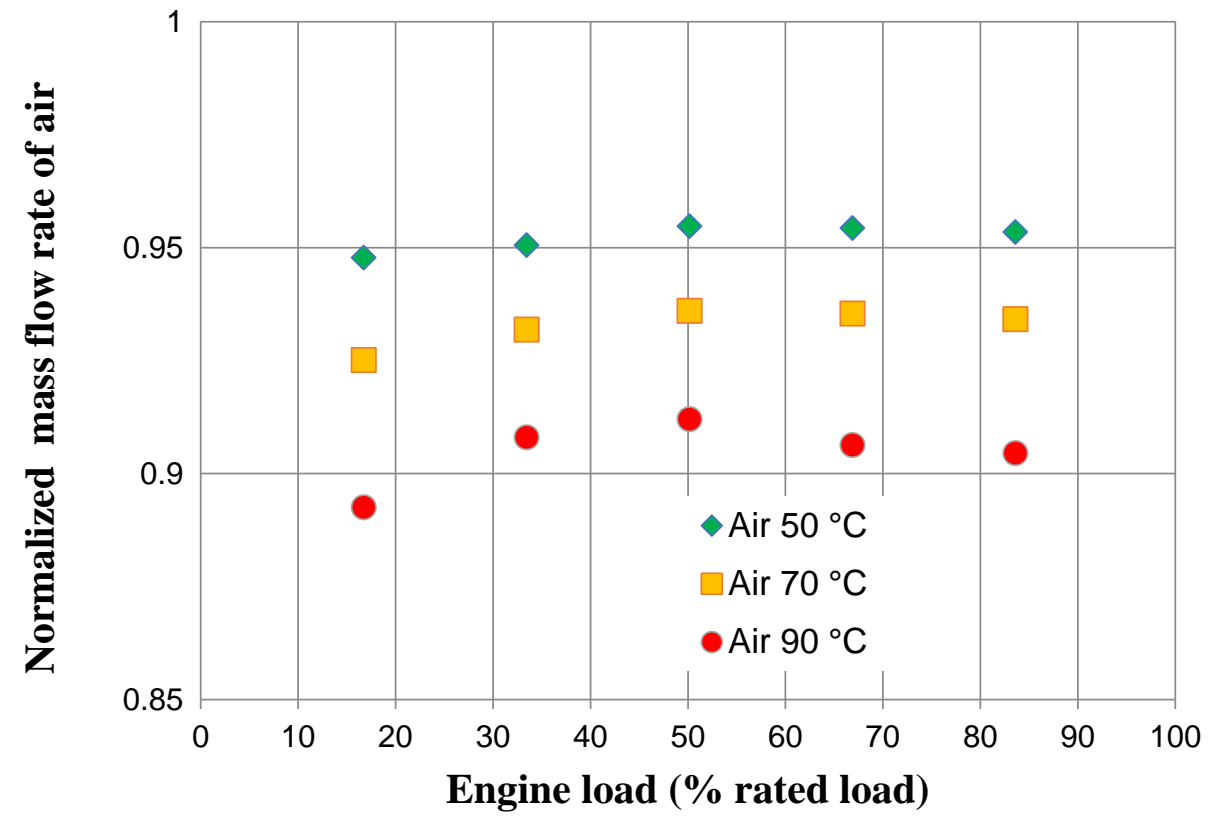

Figure 9: Experimental variations of normalized air mass.

This CAD diagram plots the change in normalized air flow rate with engine load for different preheated modes of operation. 


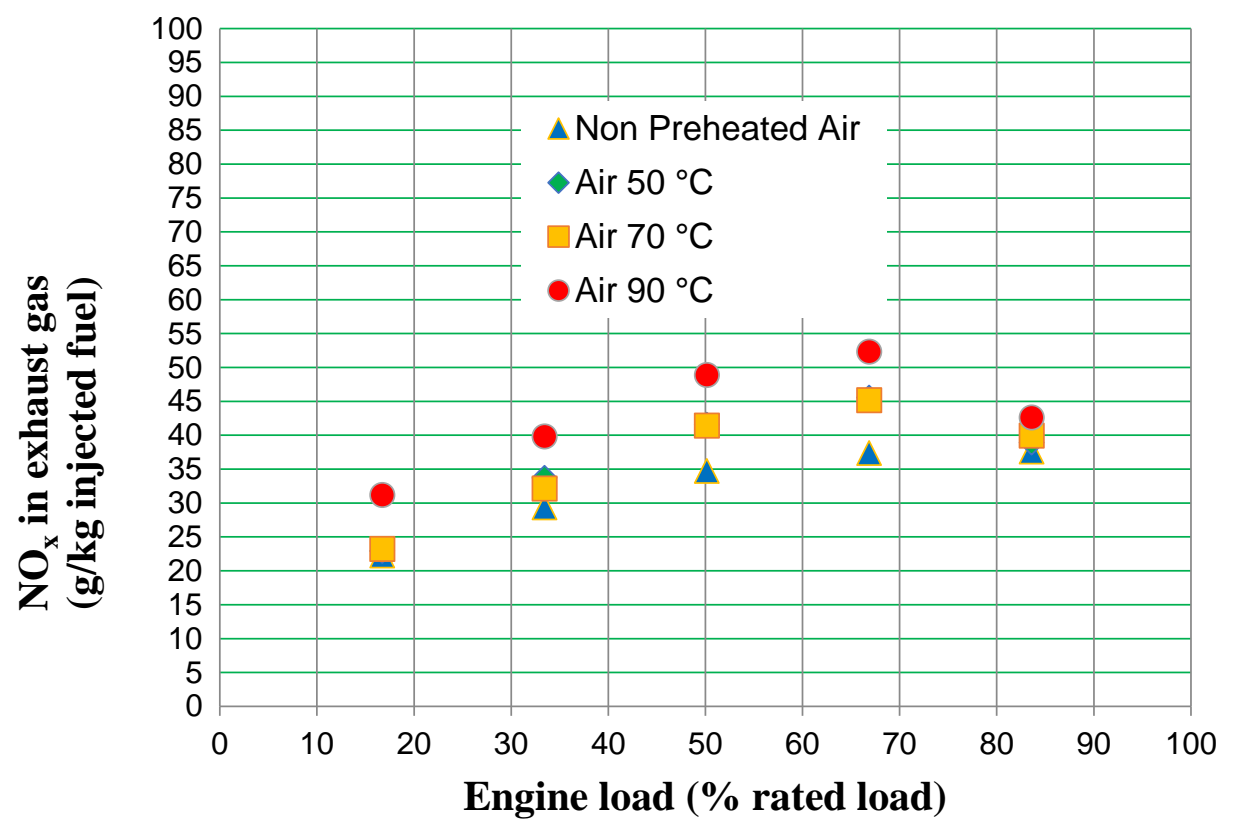

Figure 10: Experimental variation of the emission index for nitric oxides $\left(\mathrm{EINO}_{\mathrm{x}}\right)$. This CAD diagram plots the change in $\mathrm{EINO}_{\mathrm{x}}$ with engine load for different temperatures of air.

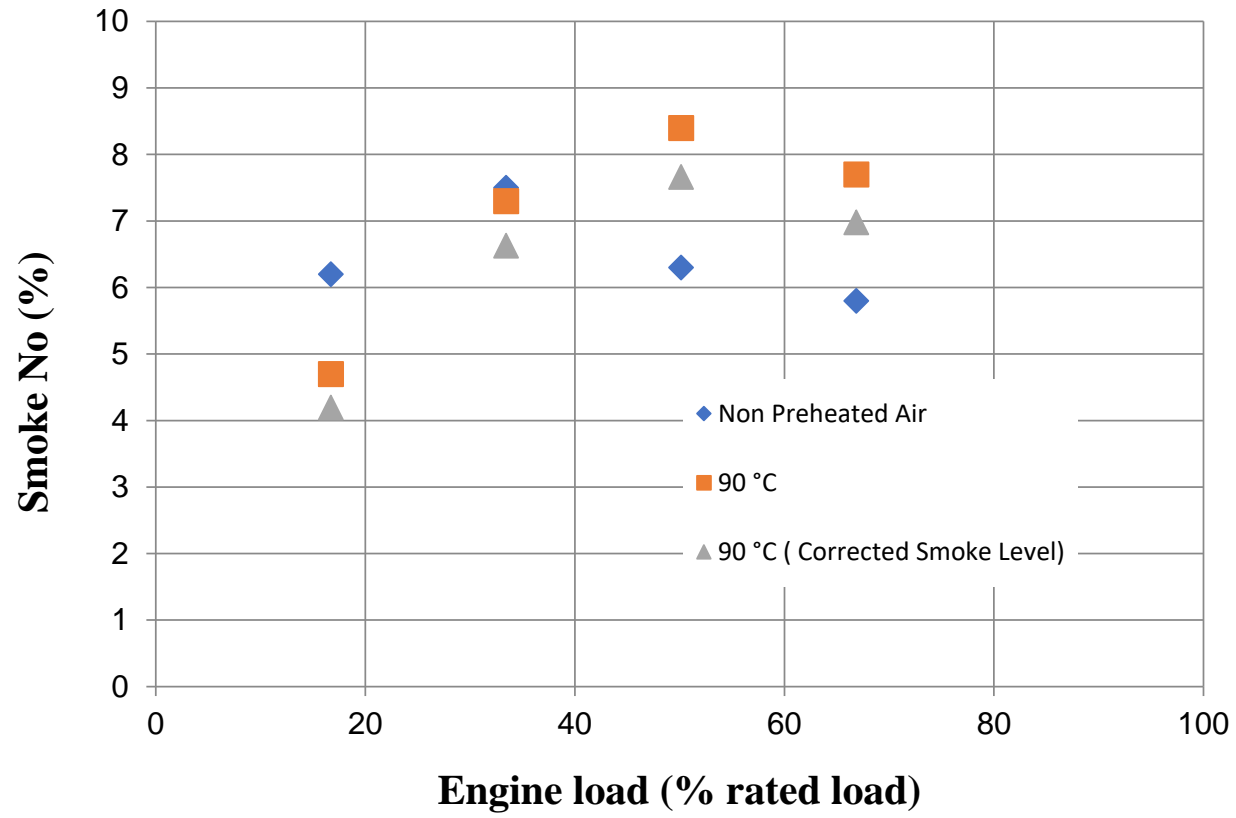

Figure 11: Experimental variation of smoke levels.

This CAD diagram plots the change in smoke levels with engine load at different opacities. 


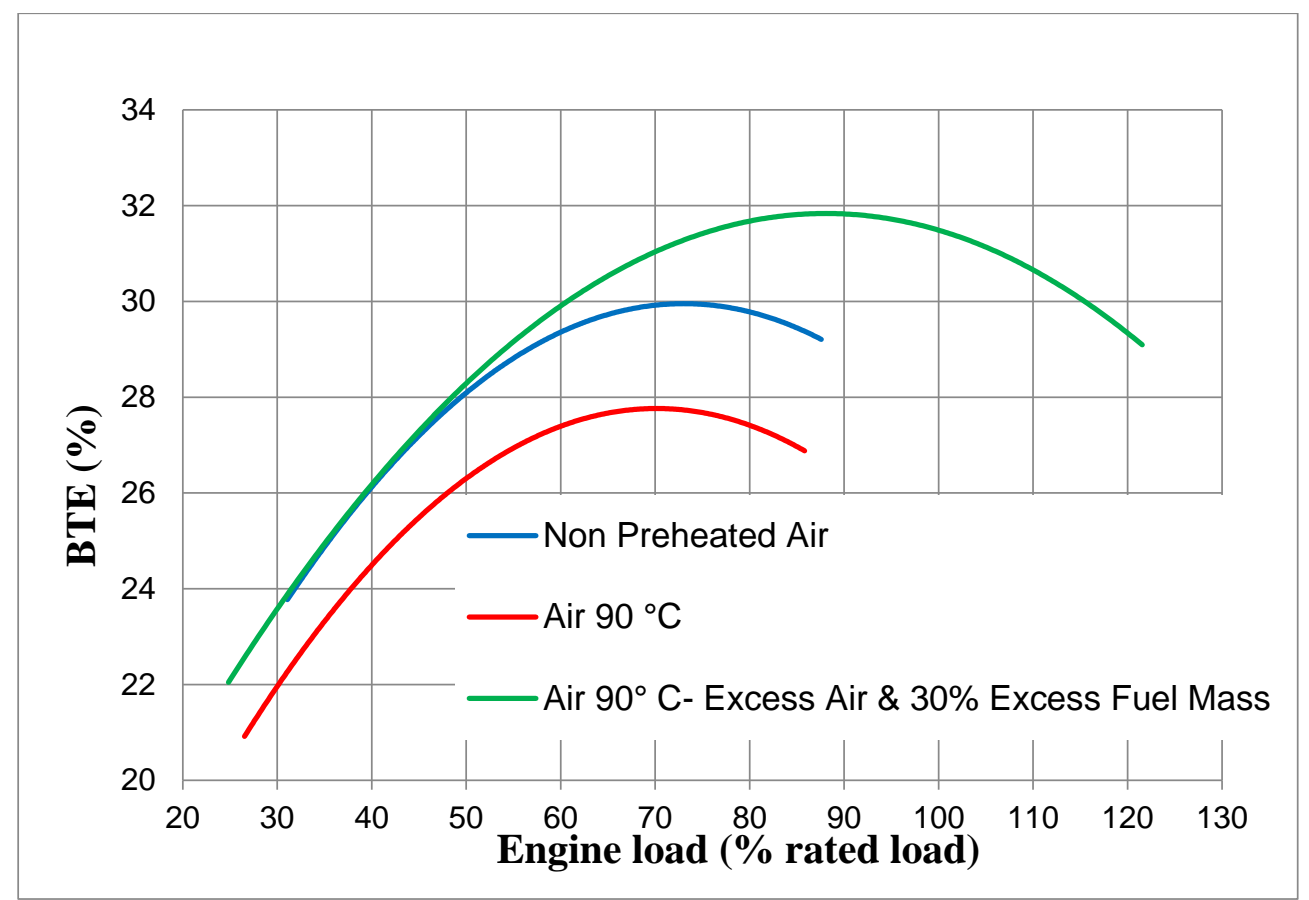

Figure 12: Variation of simulated brake thermal efficiency.

This CAD diagram plots the change in BTE with engine load at different operating conditions.

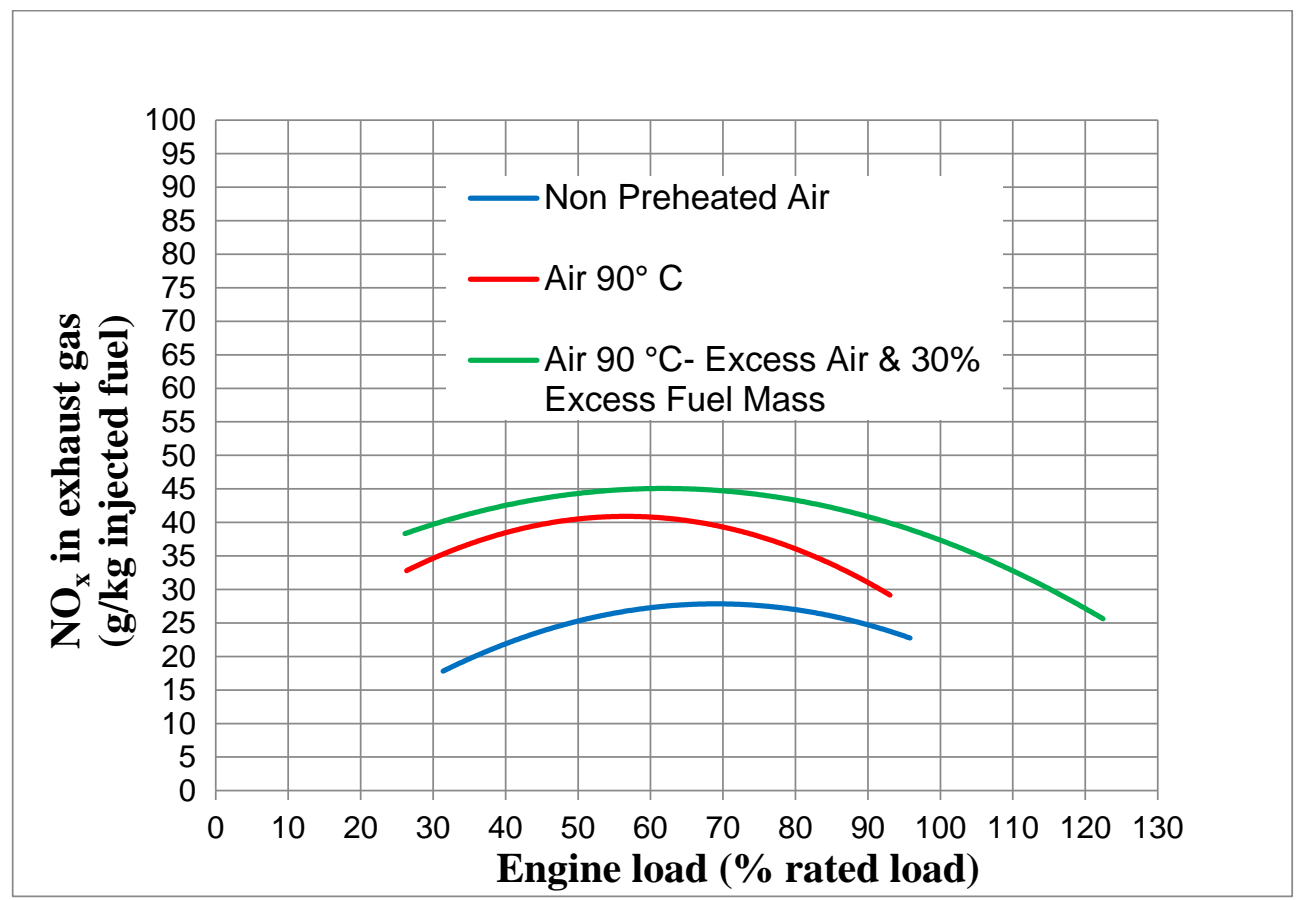

Figure 13: Variation of the emission index of nitric oxides $\left(\mathrm{EINO}_{\mathrm{x}}\right)$.

This CAD diagram plots the change in $\mathrm{EINO}_{\mathrm{x}}$ with engine load for different operating conditions. 


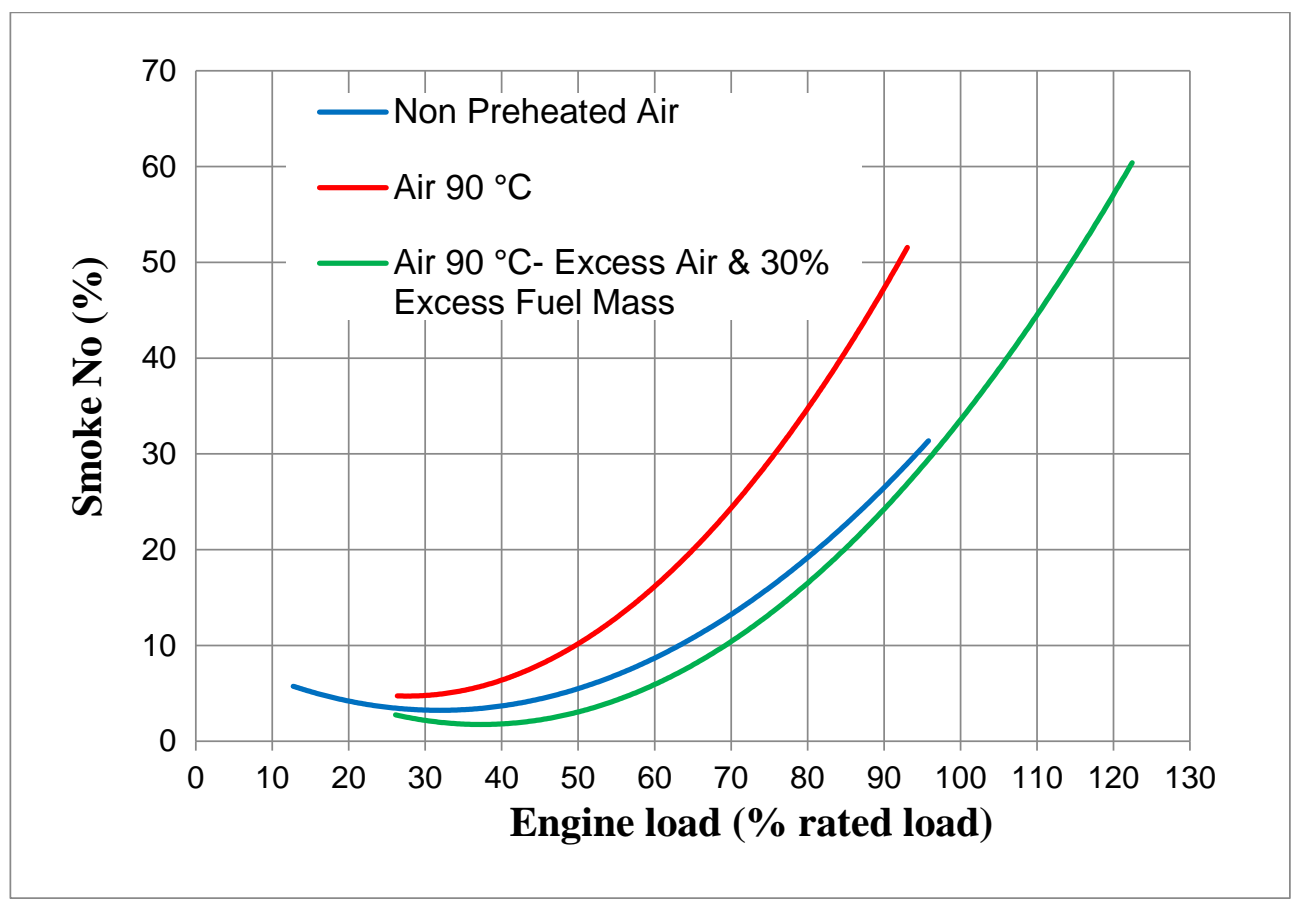

Figure 14: Variation of simulated levels of smoke emission.

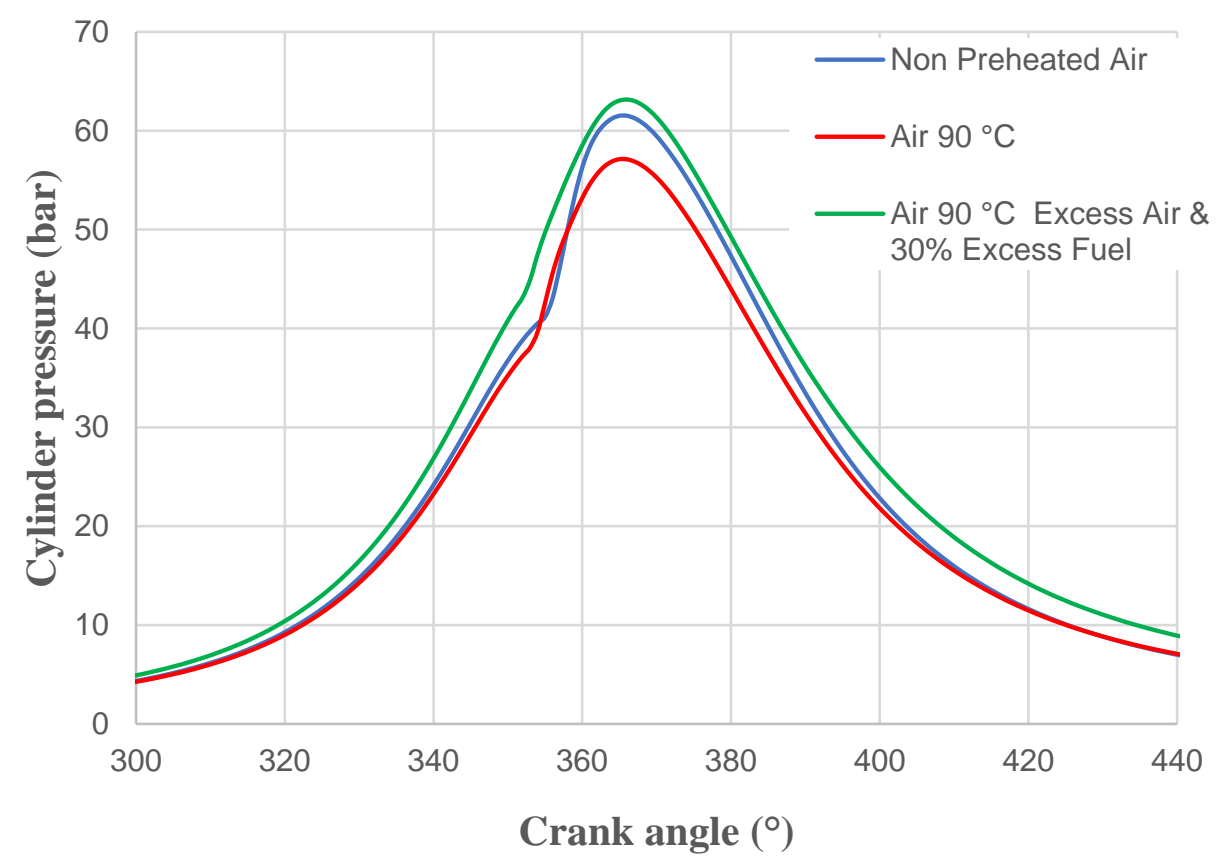

Figure 15: Variation of simulated cylinder pressure.

This CAD diagram plots the change in pressure at different crank angles. 


\section{CONCLUSIONS}

This work aimed at investigating, computationally and experimentally, the effects of preheating inlet air on the performance, combustion efficiency, and exhaust emissions of a diesel engine. This was performed by running a simulation (using the Diesel-RK software) on a single-cylinder DI diesel engine that had been modified for operations at variable intake air temperatures. The impacts of three modes of operation - air subject to no preheating, preheated air, and air preheated while retaining its own mass and increasing that of the fuel - on cylinder pressure data, engine performance, and exhaust emissions, were evaluated at different operating conditions. The key findings of this study are:

1. Peak pressure inside the cylinder reduced with increasing temperature of the inlet air. This was attributed to a shorter period of ignition delay.

2. The BTE at loads above $50 \%$ of the rated load is reduced by air preheating due to the reduction of availability of oxygen (slightly lean mixture). At low loads, the mixture is very lean so, the BTE is not affected by air preheating.

3. Thermal $\mathrm{NO}_{\mathrm{x}}$ emissions in operations involving non-preheated air were lower than those involving preheated air due to an increase in the cylinder temperature.

4. When coupled with increased air densities resulting from supercharging and an increased fuel flow rate above the rated range, preheating can improve engine efficiency, increase the rated power (i.e., the power-to-mass ratio), and reduce the smoke emission percentage.

5. The Diesel-RK simulator software can be used with reasonable accuracy.

Despite these advantages, this study is limited to the breakeven point of the brake thermal efficiency and pollutant emissions, i.e., when their values start to deteriorate. In future work, the operating parameters may be extended to include injection timing, injection pressure, the use of exhaust thermal energy for air preheating. Furthermore, additional experimental tests may be used to validate the simulation results. The findings of this study could help reduce pollutant emissions and improve the operating economics of diesel engines.

\section{References}

[1] Park SH, Kim HJ, Lee CS. Comparison of experimental and predicted atomization characteristics of high-pressure diesel spray under various fuel and ambient temperature. J. Mech. Sci. Technol. 2010;24(7):1491-1499. www.springerlink.com/content/1738-494x. DOI: 10.1007/s12206-010-0417-1.

[2] Amir K. Effect of ambient temperature and oxygen concentration on ignition and combustion process of diesel spray. Asian Journal of Scientific Research 2013;6(3):434-444, ISSN 1992-1454 / DOI: 10.3923/ajsr.2013.434.444.

[3] Jaat M, Amir K, Azwan S, Basharie SM, Adiba RA, Ramsy H. Effects of temperature and ambient pressure on spray characteristics of biodiesel combustion. Article - January 2015, DOI: 10.4028/www.scientific.net/AMM.773-774.501.

[4] Shahadat MMZ, Nabi MN, Akhter MS, Tushar MSHK. Combined effect of EGR and inlet air preheating on engine performance in diesel engine. International Energy Journal 2008;9:109-116. 
IMPROVING THE PERFORMANCE AND EMISSIONS OF A FOUR-STROKE, WATER-COOLED, DI DIESEL ENGINE BY INCREASING INLET AIR TEMPERATURE

[5] Arpan R, Gaurav R, Tushar P. Effect of intake air temperature on performance of CI engine fueled with diesel. International Journal for Scientific Research \& Development 2016;4(03): ISSN (online) 2321-0613.

[6] Mohit R, Aseem CT, Bikram S. Review on performance of CI engine by preheating of inlet air and diesel by waste heat utilization. International Journal of Innovative and Emerging Research in Engineering 2016;3(7), e-ISSN: 2394-3343, p-ISSN: 2394-5494.

[7] Jamal HW. Study on effect of heating inlet air temperature on emissions and performance of diesel engine. Journal of Applied Sciences Research 2015;11(5):28-33, ISSN 1819-544X, EISSN: 1816-157X.

[8] Vikas S, Babu JM, Naresh R, Gowthaman S, Mariappan R. Design and fabrication of air preheater for diesel engine. Research Gate 2014. DOI: 10.1007/978-81-322-1871-5_32.

[9] Hindren AS, Al-Barwari RRI, Ziyad JT. Effect of ambient air temperature on specific fuel consumption of naturally aspirated diesel engine. Journal of Science and Engineering 2013;1(1):17.

[10] Abhinay N, Vishal G, Rishabh S. Fabrication and analysis of regenerative air-preheater in diesel engine for fuel economy. International Journal of IT, Engineering and Applied Sciences Research 2015;4(3): ISSN 2319-4413.

[11] Saurabh C, Jitendra KP, Mahendra D. Performance investigation of four stroke diesel engine using preheated inlet air. International Journal of Advanced Technology in Engineering and Science 2016;4(9): ISSN 2348-7550.

[12] Mhia MZS, Mohammed NN, Mohammed SA. Diesel $\mathrm{NO}_{\mathrm{x}}$ reduction by preheating inlet air. Proceedings of the International Conference on Mechanical Engineering 2005, Dhaka, Bangladesh ,ICME05-TH-31.

[13] Pradip GK, Hole JA. Waste heat recovery from engine exhaust by using heat wheel. IOSR Journal of Mechanical and Civil Engineering e-ISSN: 2278-1684, p-ISSN: 2320-334X, 84-87.

[14] Rajesh KS, Sidhartha SR, Prabhas B, Gopabandhu D. Performance analysis of an engine by fabricating an air preheater for petrol and diesel engine. International Journal of Engineering Studies and Technical Approach 2016;2(4): ISSN 2395-0900.

[15] Rajkumar KI, Senthil KS, Dinakaran M, Gokul J. Preheating the air to the engine using Peltier effect. International Journal of Engineering Technology Science and Research 2018;5(5): ISSN 2394-3386.

[16] Siddique SA, Reddy KVK. Theoretical modelling and experimental validation of combustion in DI diesel engine by using Diesel-RK. Asian Journal of Engineering and Technology 2015;3(1): ISSN 2321-2462.

[17] Yasin MHM, Mamat R, Yusop AF, Ali MH, Izzudin MI. Study of fuel inlet temperature variations on palm biodiesel operating with a diesel engine. MATEC Web of Conferences 90 , 01079 (2017), AiGEV 2016, matecconf/20179001079.

[18] Kuleshov AS, Kozlov AV, Mahkamov K. Self-ignition delay prediction in PCCI direct injection diesel engines using multi-zone spray combustion model and detailed chemistry. SAE 2010 Commercial Vehicle Engineering Congress, ISSN: 0148-7191 e-ISSN: 2688-3627, DOI: https://doi.org/10.4271/2010-01-1960.

[19] Yasin MHM, Mamat R, Yusop AF, Idris DMND, Yusaf T, Rasul M, Najafi G. Study of a diesel engine performance with exhaust gas recirculation (EGR) system fuelled with palm biodiesel. Energy Procedia 2017;110:26-31. 
[20] Ambarish D, Mandal BK, Numerical investigation of the performance and emission parameters of a diesel engine fuelled with diesel-biodiesel-methanol blends. Journal of Mechanical Science and Technology 2016;30(4):1923-1929, DOI: 10.1007/s12206-016-0351-y.

[21] Pham VV. Research on the application of Diesel-RK in the calculation and evaluation of technical and economic criteria of marine diesel engines using unified ULSD and biodiesel blended fuel. Journal of Mechanical Engineering Research and Developments 2019;42(2):87-97. DOI: http://doi.org/10.26480/jmerd.02.2019.87.97.

[22] Charalampos Georgiou and Ulugbek Azimov," Analysis and Multi-Parametric Optimisation of the Performance and Exhaust Gas Emissions of a Heavy-Duty Diesel Engine Operating on Miller Cycle", Energies 2020, 13, 3724; doi:10.3390/en13143724

[23] Van Viet Pham, "An optimal research for diesel engine using biofuels fuel when considering the effects of the change of parameters on ECU", AIP Conference Proceedings 2207, 030002 (2020); https://doi.org/10.1063/5.0000283

[24] Shubham Mehta," Computational Investigation of Performance and Emission Characteristics of Diesel Engine Running on Soybean Biodiesel with Varying Injection Timing", International Journal of Engineering Research \& Technology (IJERT), ISSN: 2278-0181, Vol. 5 Issue 07, July2016

[25] Andrey Kuleshov, Khamid Mahkamov, Andrey Kozlov, Yury Fadeev, 2014, "Simulation of dual-fuel diesel combustion with multi-zone fuel spray combustion model," ASME 2014 Internal Combustion Engine Division Fall Technical Conference ICEF2014-5700, October 19-22, 2014, Columbus, IN, USA, $14 \mathrm{p}$. 